\title{
Calcific mediopatellar plica: a case report
}

\author{
Kalsifik mediopatellar plika: Olgu sunumu
}

\author{
İbrahim Karaman, M.D., ${ }^{1}$ Ahmet Güney, M.D., ${ }^{1}$ Kaan Gürbüz, M.D., ${ }^{1}$ Ökkeş Bilal, M.D., ${ }^{2}$ Betül Güney, M.D., ${ }^{3}$ \\ 1'Department of Orthopedics and Traumatology, Medical Faculty of Erciyes University, Kayseri, Turkey \\ ${ }^{2}$ Department of Orthopedics and Traumatology, Medical Faculty of Sütçü İmam University, Kahramanmaraş, Turkey \\ ${ }^{3}$ Department of Radiology, Medical Faculty of Erciyes University, Kayseri, Turkey
}

\begin{abstract}
A 38-year-old male patient was admitted to our clinic with the complaints of pain and swelling in his right knee for two years. He had mechanical symptoms for nearly six months. Merchant and lateral knee X-ray revealed calcification in the medial patellar retinaculum. Magnetic resonance imaging demonstrated increased ossification and cortical irregularity in the patella's medial and inferior pole. Due to long-term complaints of the patient, arthroscopy was planned with the preliminary diagnoses of patellofemoral chondromalacia, cartilage degeneration and mediopatellar plica (MPP) syndrome. Arthroscopy revealed a calcific MPP, an interesting entity. It should be kept in mind that plica may become calcific in patients with suspected MPP and the complaints of the patient may not disappear within if left untreated.
\end{abstract}

Key words: Arthroscopy; calcific plica; knee; pain.

The mediopatellar plica (MPP) is a mesenchymal tissue residue that separates the medial and lateral compartments of the knee from each other. In case of inflammation and edema, it loses its elasticity and becomes hyaline by getting fibrotic in the chronic period. One of the common reasons for cartilage degeneration developing in the medial femoral condyle and medial patella is the presence of MPP. ${ }^{[1]}$

The formation of a synovial compartment in the knee joint is a quite complex process in the embryologic period. A synovial gap forms in the $12^{\text {th }}$ week of gestation as a result of involution and absorption of synovial connective tissue. The fact that these synovial tissues cannot be resorbed and that mesenchymal tissue residues remain after birth results in the formation of synovial plicas. ${ }^{[2,3]}$ There are three types of plicas
Otuz sekiz yaşında erkek hasta kliniğimize iki yıldır devam eden sağ dizde ağrı ve şişlik yakınması ile başvurdu. Hastanın yaklaşık altı aydır mekanik semptomu vardı. Merchant ve yan diz röntgeninde iç patellar retinakulumda kalsifikasyon görüldü. Manyetik rezonans görüntülemede ise, patella iç ve alt kutbunda artmış ossifikasyon ve kortikal düzensizlik saptandı. Hastanın uzun süredir devam eden yakınmaları nedeniyle, patellofemoral kondromalazi, kıkırdak hasarı ve mediopatellar plika (MPP) sendromu ön tanıları ile atroskopi planlandı. Yapılan atroskopide ilginç bir şekilde kalsifiye MPP varlığı görüldü. Mediopatellar plika düşünülen hastalar eğer tedavi edilmezler ise, bu plikanın kalsifik hale gelebileceği ve hastanın yakınmalarının ortadan kalkmayabileceği akılda bulundurulmalıdır.

Anahtar sözcükler: Artroskopi; kalsifiye plika; diz; ağrı.

commonly reported in the knee joint: suprapatellar, mediopatellar, and inferiopatellar plicas. Despite being reported in the literature, the lateral patellar plica is rarely seen. ${ }^{[4]}$ The most common plica to cause pain in the knee clinically among these types is MPP. ${ }^{[5]}$ Four types of MPP are reported in the literature; ${ }^{[6]}$ type I rudimentary synovial plica on the anteromedial capsular wall; type II medial femoral condyle in the flexion and/or band like plica not connected with the medial facet; type III medial femoral condyle in the flexion and/or band connected with the medial facet and type IV in addition to type III, cartilage lesions are found in the femoral condyle and medial patellar facet.

We have found no evidence of plical calcification in our review of the literature. In this case, calcific MPP is presented as a type which causes MPP syndrome and

- Received: January 04, 2013 Accepted: March 18, 2013

- Correspondence: İbrahim Karaman, M.D. Alpaslan Mah., Kızılırmak Cad., Özler Sok., Vakıf-Kınaș Apt., No: 4/18, 38030 Melikgazi, Kayseri, Turkey. Tel: +90 532 - 7183353 Fax: +90352-4377686 e-mail: drikaraman@gmail.com 

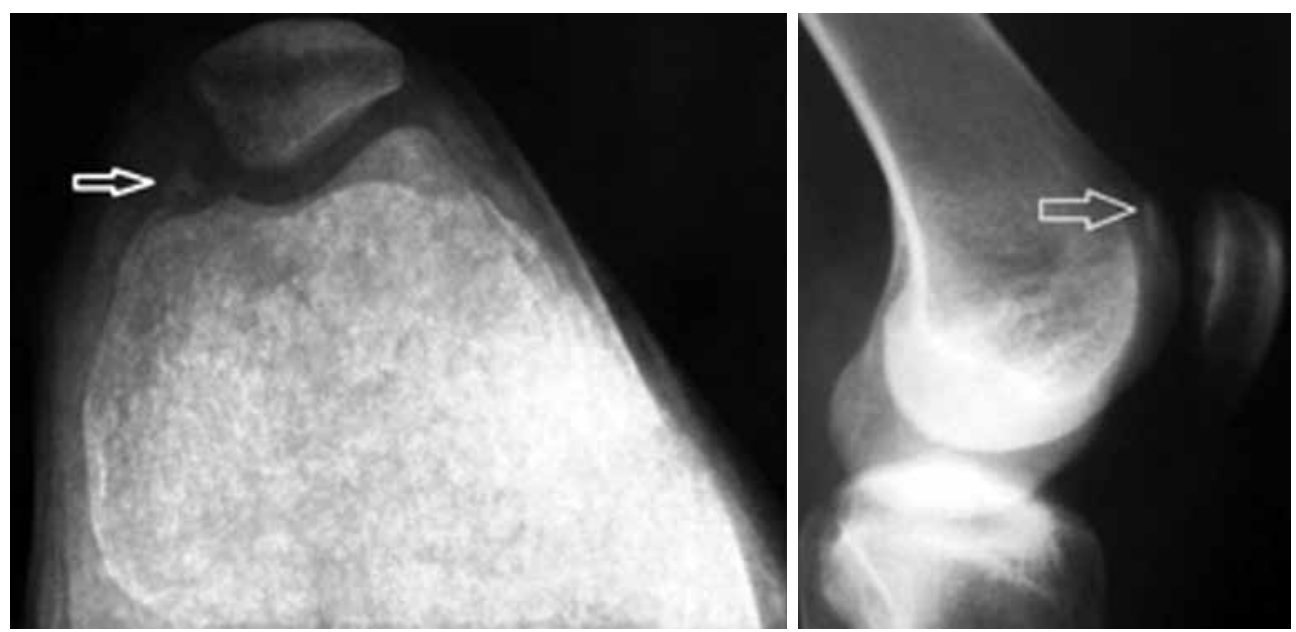

Figure 1. Radiological view of the knee, calsified pilica shown by the arrow.

is not among the classifications given above and in the literature.

\section{CASE REPORT}

A 38-year-old male patient came to our clinic with complaints of pain and swelling in his right knee for two years, and mechanical symptoms for nearly six months. Swelling and pain were found in his medial knee joint on physical examination with palpation. There was a cinema sign and a sensation of blocking. Joint range of motion was normal both actively and passively. Pumpkin and McMurray tests

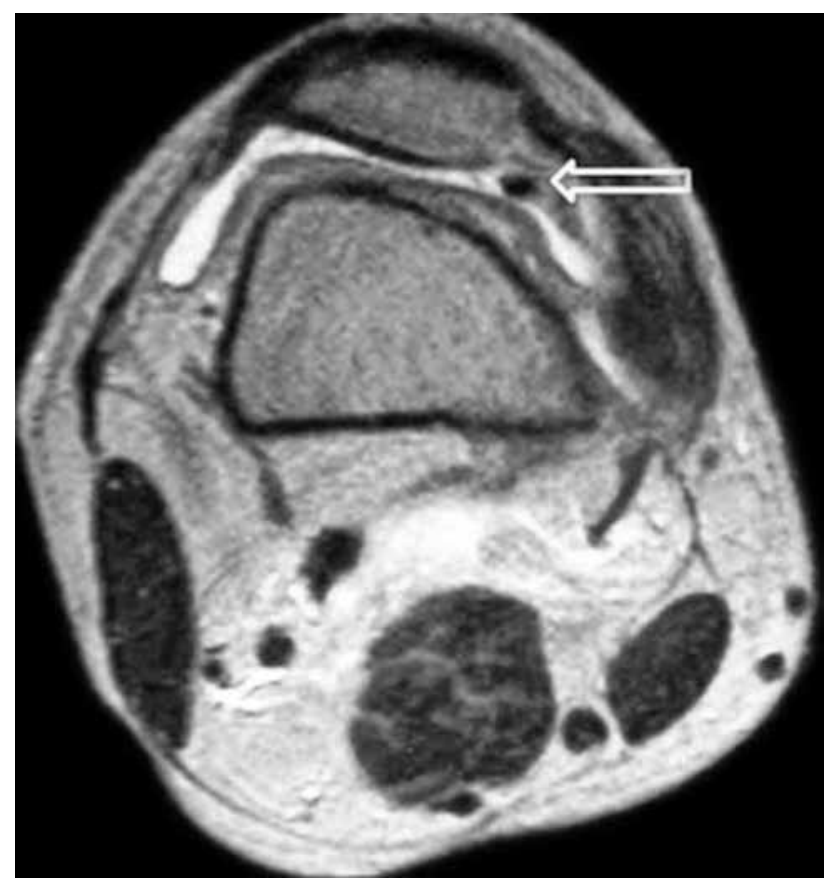

Figure 2. Magnetic resonans axial view of the knee, calsified plica shown as arrow. and terminal extension were positive. He did not have any systemic disease or drug utilization history. Radiographs showed signs of calcification starting from the patellofemoral joint extending medially and irregularity of the medial femoral condyle (Figure 1). On magnetic resonance imaging (MRI) medial femoral condyle cartilage degeneration, increased ossification and cortical irregularity in the patellar medial and inferior pole were observed (Figure 2). The preliminary diagnosis of loose body was thought to be in compliance with the patient's complaints, presence of cinema sign, and MPP syndrome, caused by changes in the patellofemoral joint. On arthroscopic examination a type B MPP was observed according to the Sakakibara classification and/or type E MPP according to the Dandy classification and it had become calcific, which was interesting (Figure 3). ${ }^{[7]}$

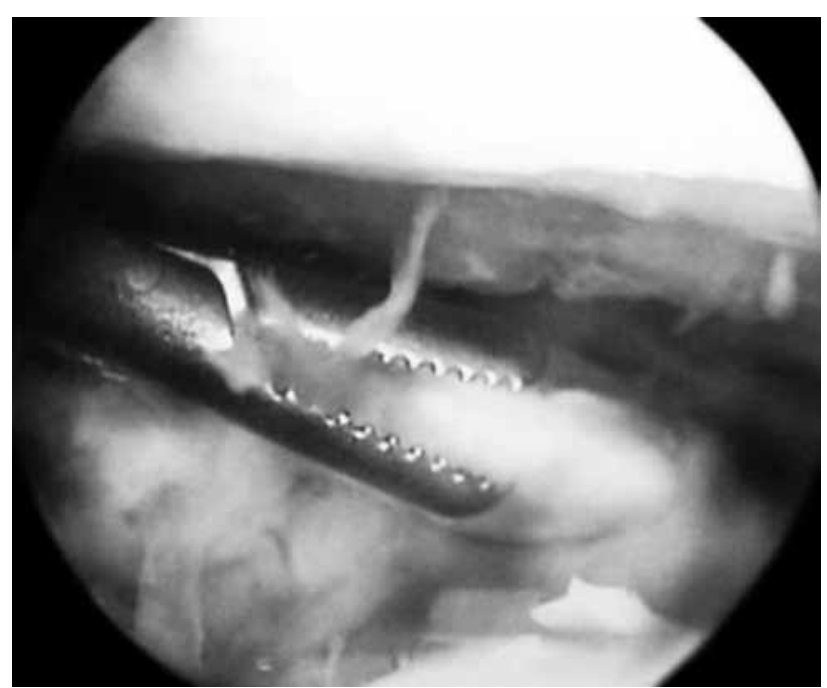

Figure 3. Athroscopical view of the mediopatellar calsified plica, examined with clamp. 

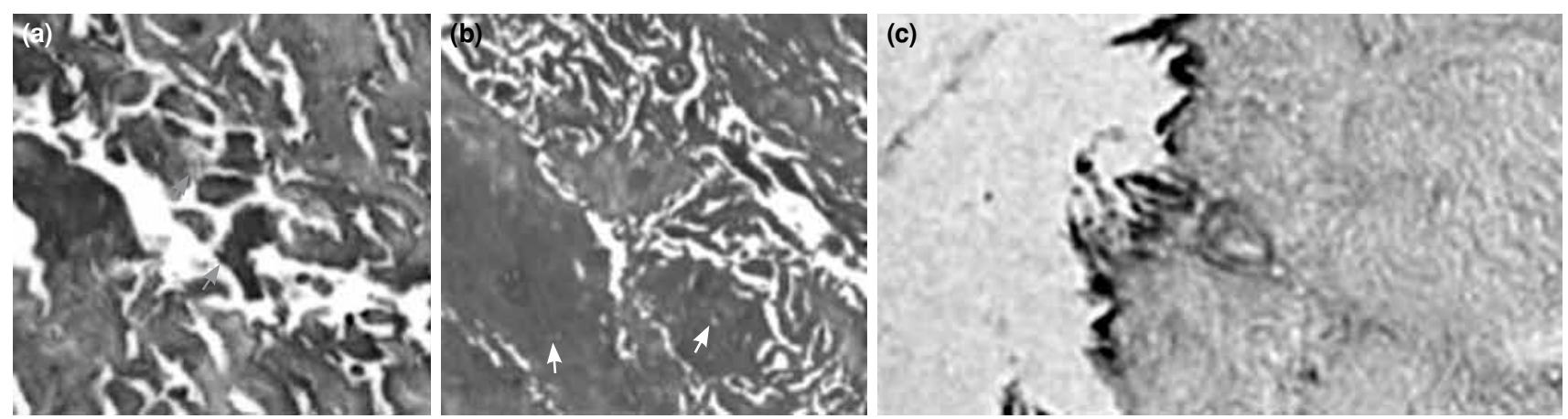

Figure 4. Light microscopy, (a) irregular collagen fibers (arrows) shown in hematoxylin and eosin staining (x 400), (b) decreased metachromasia (arrows) shown in toulidin staining (x 600), (c) increased calsification all over (x 400).

As a treatment strategy the plica was excised from the periphery towards the center without trauma to the capsule and synovial tissue. Other intraarticular structures were normal. Histopathologic examination of the excised plica revealed irregular collagen fibers, decreased metachromasia which showed degeneration of the native structure and increased calcification (Figure 4). Outerbridge type III chondral lesion was seen in the medial femoral condyle. The patient started doing postoperative isometric exercises and full weight gain standing. In the second week after the operation, the patient returned to his normal daily life. On follow up in the first month after surgery, his complaints had disappeared completely and he had no more complaints on his last follow-up at six months.

\section{DISCUSSION}

Mediopatellar femoral plica was first defined anatomically in 1939. ${ }^{[8]}$ Sakakibara $^{[6]}$ and Dandy ${ }^{[7]}$ described mediopatellar femoral plica in different ways in 1976 and 1986, respectively. These descriptions were made on the basis of anatomic localization and diversity. The worldwide arthroscopic series by Güney et al. ${ }^{[8]}$ Sakakibara ${ }^{[6]}$ and Dandy ${ }^{[7]}$ did not report any calcification of MPP. Although studies have shown that MPP causes chondral pathology, ${ }^{[1,8-10]}$ to our knowledge, there are no published reports that MPP could be calcified. Mediopatellar plica is often encountered during knee arthroscopy ${ }^{[11,2]}$ We found no data on radiologic reports of patients found to have MPP during knee arthroscopy, in the literature. ${ }^{[13]}$ We believe that the following strategies would make the diagnosis of MPP and its detection with MRI easier: taking at least 32 standard axial cross-sections in all knee MRIs, creating effusion under sterile conditions by giving an intraarticular injection to the knee of patients who have knee pain and do not respond to conservative treatment, and keeping in mind the fact that plica syndrome may be one of the reasons for anterior knee pain.

As reported in the literature, it was seen that MPP causes degeneration in the medial femoral condyle. ${ }^{[1]}$ Arthroscopic surgical excision of calcific MPP with cartilage degeneration is important in clinical treatment. In the literature, chondromalacia, grades II-III, was found in the medial femoral condyle of most patients with MPP, and this occurs because of the presence of plica. ${ }^{[1,8,14]}$ Therefore, the period between the time when the complaints first begin and arthroscopic plica excision directly affects the success of treatment and patient satisfaction. Our patient had symptoms for two years whereas and developed mechanical symptoms in the last six months which may be secondary to calcified MPP.

It should be kept in mind before an operation that plica may become calcific although its pathogenesis still remains unclear. We think that the main factor in the formation of calcification is exposure to continued microtrauma. Calcific MPP is seen rarely, and if not treated, symptoms may not disappear and may cause early medial compartment chondral damage. It is usually sufficient to perform standard excision in the rare case of finding MPP arthroscopically.

\section{Declaration of conflicting interests}

The authors declared no conflicts of interest with respect to the authorship and/or publication of this article.

\section{Funding}

The authors received no financial support for the research and/or authorship of this article.

\section{REFERENCES}

1. Guney A, Kafadar I. The plica: is a new aetiological factor in the knee osteoarthritis?. In: Chen $Q$, editor. Osteoarthritis 
- diagnosis, treatment and surgery. Croatia: InTech; 2012. p. 243-52.

2. Pianka G, Combs J. Arthroscopic diagnosis and treatment of symptomatic plica. In: Scott WN, editor. Arthroscopy of the knee. Philadelphia: W.B. Saunders Co.; 1990. p. 83-95.

3. Tindel NL, Nisonson B. The plica syndrome. Orthop Clin North Am 1992;23:613-8.

4. Patel D. Plica as a cause of anterior knee pain. Orthop Clin North Am 1986;17:273-7.

5. Broom MJ, Fulkerson JP. The plica syndrome: a new perspective. Orthop Clin North Am 1986;17:279-81.

6. Sakakibara J. Arthroscopic study on lino's band. J Jpn Orthop Assoc. 1976;50:513-22.

7. Dandy DJ. Arthroscopy in the treatment of young patients with anterior knee pain. Orthop Clin North Am 1986;17:221-9.

8. Guney A, Bilal O, Oner M, Halici M, Turk Y, Tuncel M. Short- and mid-term results of plica excision in patients with mediopatellar plica and associated cartilage degeneration. Knee Surg Sports Traumatol Arthrosc 2010;18:1526-31. doi: 10.1007/s00167-010-1125-1.

9. Urguden M, Özdemir H, Özenci A, Akyıldız F, Altınel E. Femorotibial eklemdeki kıkırdak lezyonlarının abrazyon ve drilleme ile tedavisi "Orta Dönem Sonuçları". Eklem Hastalik Cerrahisi 2003;14;7-12.

10. Yilmaz C, Golpinar A, Vurucu A, Ozturk H, Eskandari MM. Retinacular band excision improves outcome in treatment of plica syndrome. Int Orthop 2005;29:291-5.

11. Yel M, Memik R, Arazi M, Kutlu A. 1000 diz artroskopisi ile tespit edilen diz problemlerinin analizi. Eklem Hastalik Cerrahisi 2000;11:131-6.

12. Tanker U, Kılıç A. Medial sinovial plikaya artroskopik yaklaşım. Eklem Hastalik Cerrahisi 1997;8:32-3.

13. Guney A, Öner M, Argün M, BilalÖ, Kafadar İ. Mediopatellar plikada manyetik rezonans görüntülemenin artroskopik bulgularla karşılaştırılması Genel Tıp Derg 2007;17:151-5.

14. Dorchak JD, Barrack RL, Kneisl JS, Alexander AH. Arthroscopic treatment of symptomatic synovial plica of the knee. Long-term followup. Am J Sports Med 1991;19:503-7. 